To advise is about as far as men of science and engineers can go in actually fighting the War with their new weapons. The Fighting Services must use tools furnished them. Men of science can advise with some vigour and emphasis. Secrecy is necessary, of course, to keep the enemy from knowing what is being done. But secrecy can hide inaction as well as surprising, aggressive preparation. As with production and military action, the great problem is getting there first with the most and newest, and of meeting any new scientific weapon that the enemy might spring on us with an antidote within the minimum of time. The classic example of applying the antidote in this War was the neutralizing of the magnetic mines of the Germans by the degaussing belts for ships developed in Great Britain.

The 'mental front' ranks in importance with the fighting fronts in this War. It is neglected or handled piecemeal by this and that agency because it is shapeless, permeating battle lines that exist everywhere - in the United Nations and in the occupied and enemy countries. This mental front is within each of us. It is called morale or propaganda or the war of nerves. It is full of complexities and intangibles. It provides at once the greatest drive toward victory and the speediest retreat toward subjection. It is what makes the Russians-women and children as well as men-fight in the streets and scorch the earth. It is what immobilizes and makes uninterested noncombatants out of the peoples of some countries when invaders are at their front doors. The mental front is concerned with human motivation and mass emotions. It is the great neglected area in the War because it is not made of steel or tramping men.

Because of the nature of what they work with, psychologists and psychiatrists have great difficulty in forming and maintaining the lines along which they fight effectively. In part not enough is known about why human beings do things or do not do things, why they are willing to die or why they want to run away, either in ordinary life or in war. Much more is known than is being used, although more psychologists are used in this war effort than in any other. Experts in diplomacy, economic warfare and public opinion work as artists rather than scientists. Joint efforts by artists and scientists are sometimes difficult to arrange, but when accomplished often bring worthwhile results.

As science fights the war, it is also fighting for the peace to come. If this is not the case, the peace to come will be but an armistice breeding new wars. The design of the world organization to come must be on our drawing boards as our troops fight if we are to reconstruct the world in the shape we wish. More than swift, time-annihilating aeroplanes will be necessary to bind the world together in a new democratic order.

Many of the things happening in these crowded crucial months are winning the peace at home and conducting 'the people's revolution' as Mr. Henry Wallace, vice-president of the United States, has called it. To build a just, charitable and enduring peace, he has said, inspires production to the limit, transportation as rapidly as possible to the field of battle, and fighting "with all that is in us". In fighting the War, science paves the way for peace that must come. As we fight for a sane and livable world, we can be inspired by Mr. Wallace's declaration : "Modern science, when devoted wholeheartedly to the general welfare, has in it potentialities of which we do not yet dream."

\section{THE IMPACT OF SCIENCE ON AGRICULTURE}

\author{
BY SIR JOHN RUSSELL, F.R.S.
}

$\mathrm{I}^{\mathrm{N}}$ spite of considerable diversity, agricultural systems in the pre-scientific days usually possessed two features in common: they aimed first and foremost at providing complete subsistence for the community, money crops being a subordinate considera. tion; and they included measures for conserving the productiveness of the land, either by the so-called fallowing, or by letting the land revert to the wild state, or by some other device. Although these systems had a low level of productiveness they provided food for indefinitely long periods of time, and in addition possessed certain social advantages. In the system followed in Great Britain, around the Baltic, in Northern India and elsewhere, the land was divided into strips which were shared out among the participants for the purposes of ensuring equitable distribution of good and bad land. The whole complex of peasant life developed some creative art which showed itself in a love of colour, folk music and dancing, embroidery, wood carving, pottery, iron work and other peasant arts and crafts.

Unfortunately, the strip system of farming was incapable of improvement by scientific means, and as soon as the peasants insisted on a higher standard of living it had to go. The method of change varied in different countries: Russia adopted one way and Poland another. Instead of scattered strips the agricultural holding was brought into one self-contained unit. Here science was able to play its part. Unfortunately, as science came in so the peasants' arts and crafts, the colour, the singing and the dancing got somehow erowded out; they ceased to be spontaneous peasant activities and are becoming only museum pieces. It would be a great advantage to the countryside if, somehow, this apparent antagonism could be overcome.

In Great Britain the change to unified holdings had been made before the scientific era and so we were able at once to introduce science into our agriculture. It led to great improvements and in the 1860 's and 1870's our farming superiority was widely admitted. Then came a remarkable sequence of events illustrating the difficulty of anything less than 'total' application of science to agriculture. The prairies of North America were gradually being opened up for settlement. The development of implement design made cereal cultivation possible, while plant selection and breeding - then only in their early stagesprovided suitable varieties. Transport and business' agencies arranged to take and pay for the produce. A very cheap agricultural system was worked out, and the operations were on so large a scale that considerable economies were possible with the result that wheat was put on British markets at prices below those at which our farmers could grow it. Similar developments occurred in the production of butter, cheese and meat, mitigated somewhat in the latter case by the fact that British produce always had a superior quality and so had some preference in the market. Our farmers could not compete, and British agriculture fell in the 1890's to a very low level. Then a more comprehensive application of science was attempted which was gradually directed to an increase in the output per man-hour, so allowing a higher rate of wage sufficient to keep some of the men on 
the land. This effort was so far successful that before the War our output per man-hour was higher in money value than in any country in Europe. It proved very difficult, however, to combine this high output per man with high output per acre: indeed there appeared to be some sort of inverse relation between them. Our output per acre was considerably lower than in the smaller Western European countries of small holdings, and our agriculture remained solvent only by reducing the numbers of paid workers : in England and Wales the fall was from 803,000 in 1925 to 593,000 in $1937-38$.

The increased efficiency of the worker rather more than counterbalanced the fall in numbers, so that the gross value of the output rose somewhat even after allowing for differences in price.

Meanwhile a striking change had come over large sections of the prairie regions, the development of which had been the cause of so much trouble to British agriculturists. The system of agriculture proved destructive of the soil texture, the original crumb structure broke down, the soil changed to dust and in the high winds blew away. Soil erosion took place on a gigantic scale, and vast areas fell out of cultivation, some never to come back into agricultural use so far as we can see. The United States suffered most and led the way in the search for causes and remedies. It was shown that mixed farming, with alternations of grass and arable husbandry, was the surest way of preventing erosion and the best curative treatment for land not yet ruined beyond repair. But this meant a complete change in the commercial arrangements, and a reversion to the old principles, which included farming for subsistence, and the recognition of responsibility for the conservation of the soil. Far-reaching social changes are likely to result.

A somewhat different problem arose in tropical Africa and parts of India. The climate favoured the production of certain commodities of high commercial value, such as oil, fibre, tea, coffee, etc. The large supply of very cheap native labour ensured cheap production. So a plantation industry was developed and proved highly susceptible to scientific treatment; striking developments occurred. Then, however, arose certain difficulties. These new crops, helped by the aid of science, pushed out the native food crops; the subsistence agriculture gave way before plantation cropping, and the natives received pay for their work but not food. This substitution of money for food led to social difficulties, unrest, malnutrition, etc. Further, a change in the market requirements might render the produce of a whole region more or less superfluous thereby causing great financial loss : the history of sugar-cane in the West Indies is an example. In short, the intense specialization which followed the too exclusive emphasis on efficiency of production had two grave defects: it lacked the permanency of the older system and it did not adequately provide for the needs of the community.

During the past thirty years a great change has come over our ideas of administration, and it is now recognized that subsistence farming must be fully developed so as to ensure abundance of suitable food for the home population. This is necessitating a much broader utilization of science than in the earlier days.

Even in regions of the world where plantation cropping was not practised, the limited scientific intervention first attempted led to unexpected and undesirable results. The efficient medical and veterin. ary services greatly reduced the incidence of human and animal disease and so curtailed an important check on the population : the numbers of men and of animals increased and put great pressure on the land. The old system of shifting cultivation which had allowed of recuperation of fertility could no longer function : soil deterioration and in many cases soil erosion set in and a crop of troubles-social and technical-arose. These have necessitated great schemes of investigation. The general result is as before the need for a more varied type of farming, making more use of grass and leguminous crops and taking other steps to ensure soil conservation; also a larger but better organized production of crops for human and animal food; this of course involves collaboration with the veterinary and the medical staffs so as to ensure that the right foods are grown.

The War has imposed upon us in Great Britain the necessity for finding some solution of the very difficult technical problem of combining high output per acre with high output per man. The fundamental difficulty is the slowness of agricultural production, which science seems powerless to hasten. In spite of a hundred years of agricultural science crops still take as long to grow as ever they did; further, a lamb still takes five months in getting born and a calf takes nine months or more: all the big vital processes are in the main outside our control. Many of them are very dependent on season. Crops and animals are rarely ready for sale in less than 15 or 18 months after expenditure on them has begun, and as it is impossible to forecast prices for so long farmers are bound to play for 'safety first'. So it comes about that well-recognized improvements cannot be adopted because of the uncertainty whether the prices ultimately obtained will justify them. Probably there is no greater cause of frustration of agricultural science than this uncertainty about prices of produce.

In war-time this difficulty disappears and farming is virtually run on contracts, like other businesses. Prices and wages are fixed, and farmers know exactly where they are and exactly how far they can go in adopting improved methods. So in spite of almost unparalleled difficulties the output per acre now seems to be rising without any corresponding diminution in the output per man. On all grounds it is essential that British agriculture should continue to function effectively after the War. It will be needed for three purposes : (1) to help in solving the difficult social problems that will certainly arise : standards of population, national nutrition, unemployment, etc.; (2) to add to the national wealth and provide food for the community; (3) to remain as an effective protection when next a military adventurer starts a war in Central Europe.

The great need after the War will be for careful planning as to what exactly agriculture in Great Britain is wanted to do. Is it to slacken down considerably to allow of heavy imports of food for the benefit of shipping and commerce, or is it to produce as much as possible? Some sort of compromise will probably be reached. If the imports of food continued to be organized centrally it should be possible to allocate the various items among the different pro. ducing countries, giving a certain share to the home farmer at a price which enables him to pay the statutory wages without having continually to reduce the number of workers. So the difficult problem of combining high output per man with high output per acre can be solved. As an insurance against starva. 
tion in the next war it will be imperative to maintain a certain level of agricultural production.

A planned agriculture would allow of the comprehensive application of science, anything short of which may, as we have seen, have unexpectedly bad results. But the planning must not destroy the individual initiative that still remains one of the most potent factors of success in agriculture.

\section{THE FULMAR IN THE BRITISH ISLES}

\section{BY SETON GORDON, C.B.E.}

$\mathrm{T}$ HE results of the investigations into the distribution of the fulmar in the British Isles which the British Trust for Ornithology undertook during 1934-39 were published as a paper in the November issue of the Journal of Animal Ecology, 1941 (Cambridge University Press) entitled "The Breeding, Distribution, History and Population of the Fulmar (Fulmarus glacialis) in the British Isles", by James Fisher and George Waterston. The report was completed by Mr. Fisher as Mr. Waterston, now a prisoner of war in Germany, handed over his share of the work to Mr. Fisher in 1938. No one interested in the fulmar should fail to read this publication, which is one of the most interesting ornithological papers of recent years.

The spread of the fulmar, an attractive ocean bird with powerful flight that is deceptive because of its grace and apparent aimlessness, is one of the most remarkable features of British bird-life during recent decades. Until the year 1877, the fulmar bred only on the St. Kilda group of islands, which rise from the bed of the Atlantic more than one hundred miles west of the Scottish mainland. Since 1877 it has founded, up and down the coasts of Britain and Eire, no fewer than 208 colonies, in which there are estimated to be some 40,500 breeding pairs. Since the fulmar lays only one egg in the course of a season, this increase is the more remarkable.

St. Kilda has now been deserted by its human inhabitants, who were accustomed to snare the adult fulmars for oil (which they used for lighting) and food; and to take the young in the downy stage for food; and presumably, therefore, the great St. Kilda colony must now be increasing each year. But the spread of the fulmar was already taking place when the St. Kildans continued to take the fulmars for their needs, although Mr. Fisher's estimate of the number of young fulmars killed on St. Kilda in 1929 exceeds, by almost two thousand, Mr. Neil Ferguson's estimate given me of four thousand young birds taken that year.

It is not, I think, disputed that a considerable proportion of the newly founded colonies must have come from St. Kilda stock, but it seems to me probable that birds which overflowed southward from the great colonies on Iceland and the Faroe Islands have contributed to the increase. Surely, by the way, it is more likely that the Isle of Skye fulmars (p. 229) are an offshoot of the considerable colony on the Shiant Islands, twelve miles to the north, rather than arrivals from more southerly latitudes as sug. gested. Regarding the St. Kilda fulmars, Neil Ferguson, a St. Kilda man now living on the Scottish mainland, is of opinion that their spread eastwards was due, partly at all events, to their habit of following in thousands the whales that were towed from St. Kilda waters to the whaling station in Harris. This is a possibility which must not be lost sight of in seeking for the reason of the spreading, for we are told (p. 258) that fulmars first bred on Foula in 1878 when a whale was being cut up there.

The fulmar is primarily a bird of the Arctic and my memory of it in Spitsbergen is of a mountain. nesting rather than a coast-nesting species. In Britain, too, the fulmar has now founded several inland colonies. One of them, on an isolated basaltic rock on the golf course at Barnburgh in Northumberland, has, I am told, been forsaken during the present season of 1942. At this colony during a January day of easterly storm I recall watching the fulmars flying high to a considerable distance inland from that inland cliff.

The enemies of the fulmar are indeed few, but Mr. Fisher is perhaps on doubtful ground when he makes the statement that in Spitsbergen "there is no proof that the Arctic fox ever tackles the fulmar". In "Spitsbergen Papers", vol. 1, p. 330, a short account is given of a fulmar colony on a cliff amid the inland ice of Spitsbergen and of the fox tracks in the vicinity, the inference being that the foxes were preying on the fulmars, and again on p. 333 "we were rewarded by the sight of an Arctic fox making its way at great speed towards Fulmar Cliff". No definite proof, perhaps, but I have little doubt that the Arctic fox preys upon young fulmars when it has the opportunity.

In Scotland great black-backed gulls take fulmar nestlings as food for their own young. In July 1937, on the island of Hoy, I disturbed, beside a freshwater loch, a large great black-backed colony. One of the young gulls when alamed disgorged a complete young fulmar which it must have swallowed only a few minutes before. The neighbouring cliffs on which the fulmars were nesting had not been disturbed that day through human agency, and the inference therefore is that the parent gull must either have driven the parent fulmar from its young, or must have come upon the young one unattended. When young fulmars disappear (as they often do) from a colony, I suspect that it is the work of the great black-backed gull.

Mr. Fisher has found that the breeding colonies of fulmars arrive earlier at their rocks than the birds which are founding colonies but have not actually bred. But the small Bamburgh colony, even when that colony was in process of being founded, arrived at their inland rock so early as the end of December or beginning of January, whereas at their breeding colony in the north of Skye the birds have not been noted on the ledges before February. Perhaps the fact that the two colonies are on opposite coasts of Britain may account for this difference in the times of arrival, but it is nevertheless worth recording.

Mr. Fisher's paper is full of interesting information. Who, for example, was aware that fulmars have been on occasion shot with young peduncled barnacles growing upon the feathers of their under parts (p. 256) ? Or, that a fisherman's minnow bait was taken by a fulmar on fresh water 400 miles from the sea (p. 257) ? One would have liked to have been told more about that remarkable occurrence.

It is pointed out that the nesting site of the fulmar is rather different from the sites of other cliff-nesting birds, for it is usually a steep slope of $60^{\circ}$ or more 